\title{
Guest Editors' Introduction to JLAS Special Issue on Athlete Activism and Sports Social Responsibility
}

\author{
Arthur R. Miller and Jodi S. Balsam*
}

When San Francisco 49ers quarterback Colin Kaepernick knelt during the national anthem prior to National Football League (NFL) games during the 2016 season, he quickly became a symbol of a renewed era of athlete activism, triggering collegiate and professional athlete activists across the country to join demonstrations and sparking national conversations about racism and police brutality. But athlete activism is much broader, extending to philanthropic work such as NFL wide receiver Brandon Marshall's efforts to spread mental health awareness and National Basketball Association superstar LeBron James's funding of college scholarships for inner-city youth. Professional athletes' willingness to take public stands on political and social issues is reflected and reinforced by sports entities' social responsibility initiatives. For example, the NCAA relocated men's basketball championship games out of North Carolina in response to a state law that curbed anti-discrimination protections for transgender people. Most sports leagues and governing bodies regularly participate in socially responsible causes.

In short, the sports industry has adapted the tenets of corporate social responsibility to fit its uniquely visible profile and serve its communities. Consequently, a constant stream of information can be found in news reports that showcase league, team, and player efforts to make sports healthier and safer at all levels, improve literacy, create and fill jobs, address gender and racial inequalities, fight disease and poverty, prevent substance abuse, address domestic violence, and clean up the environment. However, in staking out positions on political, social, and health questions, sports industry participants face legal ramifications and risk.

This special issue of the Journal of Legal Aspects of Sport examines both public and private law issues that arise whenever individuals and organizations among the complex network of relationships that define the sports industry try to make socially responsible choices or engage in social or political activism. We come to this topic as scholars and teachers of sports law, but also as observers of sports as a reflection of the most fundamental norms and values that shape

\footnotetext{
* Arthur R. Miller, LLB, is a University Professor at the New York University (NYU) School of Law and director of the NYU Sports and Society program; email: arthur.r.miller@nyu.edu. Jodi S. Balsam, JD, is an associate professor of clinical law and director of Externship Programs at the Brooklyn Law School, and an adjunct professor of law at the NYU School of Law; email: jodi.balsam@brooklaw.edu
} 
human society. Arthur R. Miller is one of the nation's foremost legal experts on a variety of subjects, and is an Emmy winner for his work on PBS's "The Constitution." He founded the NYU Sports and Society program in recognition of the immense social, economic, cultural, and geopolitical impact of sports. Jodi $\mathrm{S}$. Balsam practiced sports law as a litigator and in-house league lawyer for 20 years, writes and comments on current sports law issues, and is a co-author of a leading casebook used in sports law courses. We aspire to elevate the discourse about social responsibility in sports by improving understanding of related legal and ethical rights and obligations. The articles in this special issue are authored by an impressive array of scholars, activists, and sports industry leaders, and offer a diverse set of perspectives on sports social responsibility.

Lisa Borders, the President of the Women's National Basketball Association, came to the sports world from a storied career in business and politics. She writes movingly about childhood memories of the civil rights movement and how the ideals of equality, justice, and freedom were contested on the fields of sports in addition to the courts and polling booths. She offers principles for renewed athlete activism that balance the rules of the game with constructive protests, community engagement, and empowerment of women and others whose voices are not sufficiently heard.

Sports social responsibility efforts differ from other industries in the degree to which professional teams are embedded in their communities and can influence community well-being. The paired papers of Brendan Parent and Jason Chung lay important groundwork for this special issue based on extensive research into how various sports constituencies define and implement social responsibility, and measure its impact in terms of benefitting the community and generating goodwill.

Among the most vulnerable populations involved in athletics are youth sports participants, dependent on parents, coaches, and other responsible adults to help them make healthy choices regarding their sports participation. Phoebe Friesen, Bethany Saul, Lisa Kearns, Kathleen Bachynski, and Arthur Caplan explore the public health challenge of overuse injuries in youth sports, the limits on available legal remedies, and the social responsibility to educate relevant actors and shift youth athletics toward safer training practices.

Global sport proclaims powerful and universal ideals including human rights. Yet its governance systems do not always respect the individual dignity of the athlete or cultivate environments for training and competition that are free of discrimination and abuse. Brendan Schwab is executive director of the World Players Association, which advocates for athletes in the governance of world sport. His paper examines episodes of individual and collective athlete activism on the global sport stage, and offers an ethical framework for embedding internationally recognized human rights into institutional sports governance.

The Syrian refugee crisis provides a stark backdrop for the power of sport to offer humanitarian relief. Elizabeth Cheung-Gaffney provides an overview of international refugee law and the degree to which it supports access to sport as a means to promote education, health, development, and peace. She conducts a case study of a soccer program at a Jordan refugee camp, executed in a coordinated and strategic way to meliorate the daily existence of displaced youth. 
Social responsibility in sports extends beyond doing good deeds and partnering with the community in philanthropic or social justice efforts. It requires leagues to develop appropriate responses to the bad deeds of some of their participants. Amanda Zink examines the NFL's response to player off-field misconduct, focusing on domestic violence and drug abuse, to argue that current disciplinary procedures and punitive measures are misguided and overlook opportunities to engage with the community and develop rehabilitative strategies that have real public health impact.

In the aggregate, these studies and commentaries provide a narrative backdrop and positive insights for sport participants to move forward in their social responsibility efforts. Our hope is that these articles find multiple audiences, not only sports law and business scholars, but also social justice activists, humanitarian organizations, and sports governing bodies who have much to offer each other in terms of confronting injustice and affirming the power that sports have to change public opinion and the society in which we desire to live.

We are grateful to the entire editorial and organizational staff at the Journal of Legal Aspects of Sport (JLAS), both for their readiness to devote a special issue to this urgent topic and for their steadfast encouragement and assistance throughout the process. A special thanks to $J L A S$ editor-in-chief Thomas A. Baker, who wholeheartedly supported this special issue and demonstrated remarkable equanimity and confidence in the guest editors. We also thank those who contributed their time and expertise in reviewing and editing the papers that were submitted and shaping them into the top-notch work featured in this issue. 